\title{
Value of High Sensitive CRP in Hyperglycemic Patients with Acute Coronary Syndrome.
}

\author{
Alaa Ez El-Deen Said , Resident in Internal Medicine Department , Sohag \\ university Hospitall. \\ Omar Saad Mohammed, Lecturer of Internal Medicine1. \\ Yasser Mohammed Kamal , assistant professor of Internal medicine1.
}

Adel Abdel-Aziz El-Sayed, Professor of Internal medicine1.

\begin{abstract}
BACKGROUND: Hyperglycemia on admission in patients with acute coronary syndromes is common, and it is a powerful predicator of increased risk of in hospital complications in patients with and without diabetes mellitus, high sensitivity creactive protein (hs- CRP) is a cardiovascular risk marker in patients with acute coronary syndrome.
\end{abstract}

\section{OBJECTIVES:}

1. To determine the levels of high-sensitivity C-reactive protein (hs-CRP) in subjects of acute coronary syndrome with admission hyperglycemia whatever diabetic or not.

2. To determine the levels of high-sensitivity C-reactive protein (hs-CRP) in subjects of acute coronary syndrome without admission hyperglycemia.

3. To compare the results of the above two groups and assess the prognostic value of admission glucose and hs -CRP levels in hyperglycemic patients with acute coronary syndromes.

DESIGN AND SETTING: Prospective study, at Sohag university hospital in Egypt.

METHODS: We measured the blood glucose, hs -CRP, cardiac enzymes and HBAIC levels at admission in 100 consecutive patients with ACS. Glucose was categorized as $\leq 11.1 \mathrm{mmol}=<200 \mathrm{mg} / \mathrm{dl}$ and $\geq 11.1 \mathrm{mmol}=>200 \mathrm{mg} / \mathrm{dl}$. hs - CRP negative $<1$ and positive $>3 \mathrm{mg}$, HBAIC $\leq 6.5 \%$ or $\geq 6.5$ ).

RESULTS: In our study reveals a statistically significant relation between levels of admission glucose and left ventricular function (LV failure, pulmonary edema and cardiogenic shock) or arrhythmias in hyperglycemic patients with ACS $(\mathrm{P}<0.0001)$. Also there is a significant relation between level of hs- CRP and LVF and type of myocardial infarction in-hospital complications.

Also there is insignificant relation between HBAIC levels and left ventricular function in ACS at admission.

CONCLUSION: We conclude that elevated admission glucose appears a more important in predicting in-hospital and short term complications particularly left ventricular failure and cardiogenic shock in patients with acute coronary syndromes. Also the increased levels of hs- CRP are a predictor for severity and extent of myocardial damage and left ventricular function especially in STEMI.

The synergistic effect of associated both stress hyperglycaemia and hs- CRP is a strong predictor for poor ACS outcome.

KEYWORDS: High-sensitivity C-reactive protein level, Hyperglycemia, Inflammatory marker, Atherosclerosis ,Acute coronary syndrome. 


\section{INTRODUCTION}

Over the last decades, evidence has accumulated that systemic inflammatory activity plays a key pathogenic role in atherosclerosis and cardiovascular disease (CVD) (1).

This rationale has led to a search for clinically useful inflammatory biomarkers to improve CVD risk prediction . Prominent among possible candidates is C-reactive protein (CRP) as measured by a highly sensitive assay (2).

C-reactive protein represents the classical acute-phase protein produced in the liver in response to inflammatory stimuli, and plasma levels of high-sensitive $\mathrm{C}$ reactive protein (hs-CRP)provide a sensitive marker of increased inflammatory activity in the arterial wall (3).

Insulin resistance correlates closely with the risk of CVD, explaining some of the excess mortality in type 2 diabetes patients .There appears to be more-or-less linear relationship of cardiovascular risk to insulin resistence across the spectrum of normoglycemic patients with insulin resistence up to presenting with overt type 2 diabetes (4).

Different studies revealed that hyperglycemia on admission in patients with acute coronary syndromes is common, and it is a powerful predicator of survival and increased risk of in-hospital complications in patients with and without diabetes mellitus(5).

Diabetic patients have generalized higher inflammatory state compared with nondiabetic patients, even in the context of ACS. The level of HS CRP correlates significantly with severity of myocardial lesion in ACS.

\section{METHODS}

\section{Patients:}

The study included 100 consecutive patients admitted with acute coronary syndrome in Sohag university hospital from December 2016 to April 2017. It included 48 patients with ST segment elevation myocardial infarction (STEMI) and 30 Patients with Non ST segment elevation myocardial infarction and 22 patients with unstable angina.

*Inclusion Criteria; a. Above 18 years. b. Hyperglycemic patients with ACS (whatever previously diagnosed diabetic or not).

* Exclusion Criteria; Patients with preexisting or acute inflammatory process ,malignancy or collagen diseases were excluded.

\section{Measurements}

For all patients, full history taking, clinical examination and serum glucose level assessment on admission were done. Serial cardiac enzymes (troponin I and CKMB), glycosylated haemoglobin (HBAIc), hs CRP, serial ECG and complete echo-Doppler study were obtained. Follow up clinical examination and assessment of complication was done for one month after admission.

Diabetes was defined as the use of insulin or glucose-lowering medication on admission, or a diet for diabetes documented in medical history. Patients were categorized according to glucose level at admission $(<200 \mathrm{mg}$ or $>200 \mathrm{mg} / \mathrm{dl}=>11.1 \mathrm{mmol} / \mathrm{l}$ ), based on values reported by the world health organization for

diagnosing diabetes and according to admission $\mathrm{HbA} 1 \mathrm{c} \quad(<6.5 \%$ and $\geq$ $6.5 \%)$.

Statistical Analysis of all Results was done using descriptive statistics Analysis. 


\section{RESULTS}

Patients included in the study have a mean age of $61.07 \pm 7.36$ years. All patients were diabetics with admission glucose ranged from( $103-430$ ) a mean $239.08 \pm 85.82$ $\mathrm{mg} / \mathrm{dl}$. Admission glucose was categorized as $(<200 \mathrm{mg} / \mathrm{dl}$ and $\geq 200 \mathrm{mg} / \mathrm{dl})$.

HbAIC level was also included as a continuous and categorized $(\leq 6.5 \%$ and $\geq 6.5 \%)$.

Hs C-reactive protein levels were measured in all patients including STEMI \& NSTEMI.

In the studied patient with acute coronary syndromes the incidence of left ventricular failure increased incrementally with the levels of admission hyperglycemia either clinically as assessed by killip classification or by echocardiographic ejection fraction (EF\%) which is statistically significant.

Also there is a significant relation between increased level of hs-CRP with STEMI versus NSTEMI $(\mathrm{P}<0.0001)$. There is no significant relationship between level of glycosylated haemoglobin level and left ventricular function at admission or short term complications.

\section{STATISTCS}

Relation between hyperglycemia and characteristics of studied population:

\begin{tabular}{|c|c|c|c|}
\hline Variable & $\begin{array}{l}\text { Group I } \\
\text { No } \\
\text { hyperglycemia } \\
\mathbf{N = 2 6} \\
\end{array}$ & $\begin{array}{l}\text { Group II } \\
\text { Hyperglycemia } \\
\text { N=74 }\end{array}$ & $P$ value \\
\hline $\begin{array}{l}\text { Age/years } \\
\text { Mean } \pm \text { SD } \\
\text { Median (range) }\end{array}$ & $\begin{array}{l}61.38 \pm 8.68 \\
65(48-75)\end{array}$ & $\begin{array}{l}60.95 \pm 6.90 \\
61(48-75)\end{array}$ & 0.80 \\
\hline $\begin{array}{l}\text { Gender } \\
\text { Females } \\
\text { Males } \\
\end{array}$ & $\begin{array}{l}8(30.77 \%) \\
18(69.23 \%)\end{array}$ & $\begin{array}{l}28(37.84 \%) \\
46(62.16 \%)\end{array}$ & 0.52 \\
\hline $\begin{array}{l}\text { Smoking } \\
\text { Current smoker } \\
\text { Ex-smoker } \\
\text { Non-smoker }\end{array}$ & $\begin{array}{l}8(30.77 \%) \\
6(23.08 \%) \\
12(46.15 \%)\end{array}$ & $\begin{array}{l}22(29.73 \%) \\
20(27.03 \%) \\
32(43.24 \%)\end{array}$ & 0.92 \\
\hline $\begin{array}{l}\text { Hypertension and } \\
\text { Treatment } \\
\text { Non-hypertensive } \\
\text { ACEIS } \\
\text { B-blocker \& diuretics } \\
\text { B-blocker } \\
\text { CCB } \\
\text { Diuretics }\end{array}$ & $\begin{array}{l}18(6923 \%) \\
4(15.38 \%) \\
0 \\
2(7.69 \%) \\
2(7.69 \%) \\
0\end{array}$ & $\begin{array}{l}42(56.76 \%) \\
8(10.81 \%) \\
2(2.70 \%) \\
16(21.62 \%) \\
4(5.41 \%) \\
2(2.70 \%)\end{array}$ & 0.48 \\
\hline Diabetes and treatment & & & \\
\hline $\begin{array}{l}\text { Not } \\
\text { Stress hyperglycemia } \\
\text { 1st diagnosed }\end{array}$ & $\begin{array}{l}26(100 \%) \\
0 \\
0\end{array}$ & $\begin{array}{l}0 \\
22(29.73 \%) \\
16(21.62 \%)\end{array}$ & \\
\hline Insulin & $\mathbf{0}$ & $14(18.92 \%)$ & $<0.0001$ \\
\hline $\begin{array}{l}\text { Metformin } \\
\text { Metformin \& pioglitazone } \\
\text { Sulfonylurea }\end{array}$ & $\begin{array}{l}\mathbf{0} \\
\mathbf{0} \\
\mathbf{0}\end{array}$ & $\begin{array}{l}14(18.92 \%) \\
2(2.70 \%) \\
6(8.11 \%)\end{array}$ & \\
\hline
\end{tabular}


Relation between hyperglycemia and pattern of ACS:

\begin{tabular}{|l|c|c|c|}
\hline \multicolumn{1}{|c|}{ Pattern of ASCs } & $\begin{array}{c}\text { Group I } \\
\text { No } \\
\text { hyperglycemia } \\
\text { N=26 }\end{array}$ & $\begin{array}{c}\text { Group II } \\
\text { Hyperglycemia } \\
\text { N=74 }\end{array}$ & P value \\
\hline UA & $10(38.46 \%)$ & $12(16.22 \%)$ & \\
NSTEMI & $6(23.08 \%)$ & $24(32.43 \%)$ & 0.06 \\
STEMI & $10(38.46 \%)$ & $38(51.35 \%)$ & \\
\hline
\end{tabular}

Comparison between patients with and without hyperglycemia as regard pattern of ACS:

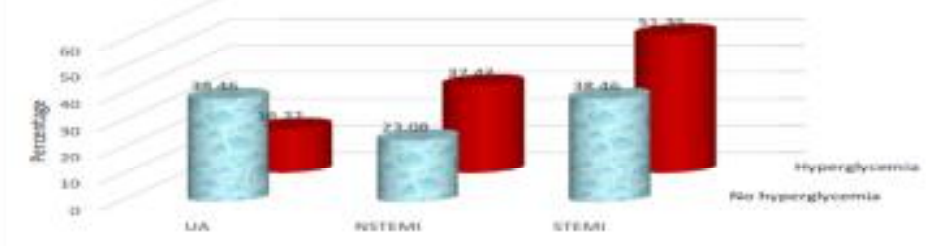

Relation between hyperglycemia and HS-CRP :

\begin{tabular}{|c|c|c|c|}
\hline HS-CRP & $\begin{array}{c}\text { Group I } \\
\text { No } \\
\text { hyperglycemia } \\
\text { N=26 }\end{array}$ & $\begin{array}{c}\text { Group II } \\
\text { Hyperglycemia } \\
\text { N=74 }\end{array}$ & P value \\
\hline HS-CRP $<1 \mathrm{mg} / \mathrm{dl}$ & $20(76.92 \%)$ & $10(13.51 \%)$ & $<0.0001$ \\
HS-CRP $>3 \mathrm{mg} / \mathrm{dl}$ & $\mathbf{6 ( 2 3 . 0 8 \% )}$ & $\mathbf{6 4}(\mathbf{8 6 . 4 9 \% )}$ & \\
\hline
\end{tabular}

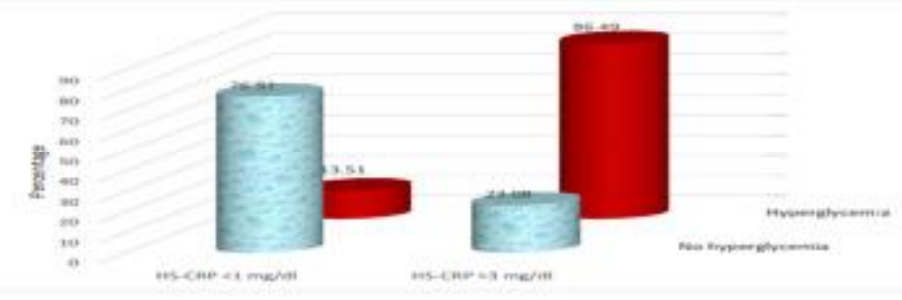

Comparison between patients with and without hyperglycemia as regard Admission CRP (mg/dl) :

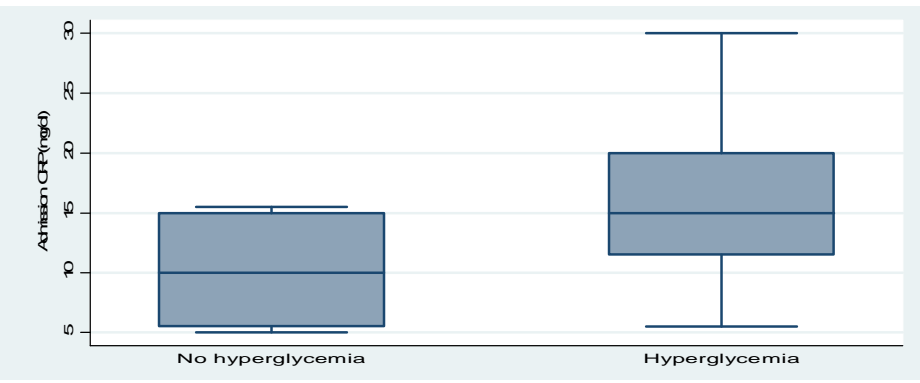


Relation between hyperglycemia and In- hospital complications:

\begin{tabular}{|l|c|c|c|}
\hline \multicolumn{1}{|c|}{ In hospital complications } & $\begin{array}{c}\text { Group I } \\
\text { No } \\
\text { hyperglycemia } \\
\text { N=26 }\end{array}$ & $\begin{array}{c}\text { Group II } \\
\text { Hyperglycemia } \\
\text { N=74 }\end{array}$ & P value \\
\hline Cardiogenic shock & 0 & $2(2.70 \%)$ & \\
Hear block & 0 & $10(13.51 \%)$ & \\
HF KILLIP CLASS I & $16(61.54 \%)$ & $8(10.81 \%)$ & $<0.0001$ \\
HF KILLIP CLASS II & $4(15.38 \%)$ & $18(24.32 \%)$ & \\
HF KILLIP CLASS III & $6(23.08 \%)$ & $28(37.84 \%)$ & \\
HF KILLIP CLASS IV & 0 & $8(10.81 \%)$ & \\
\hline
\end{tabular}

\section{Comparison between patients with and without hyperglycemia as regard In-} hospital complications:

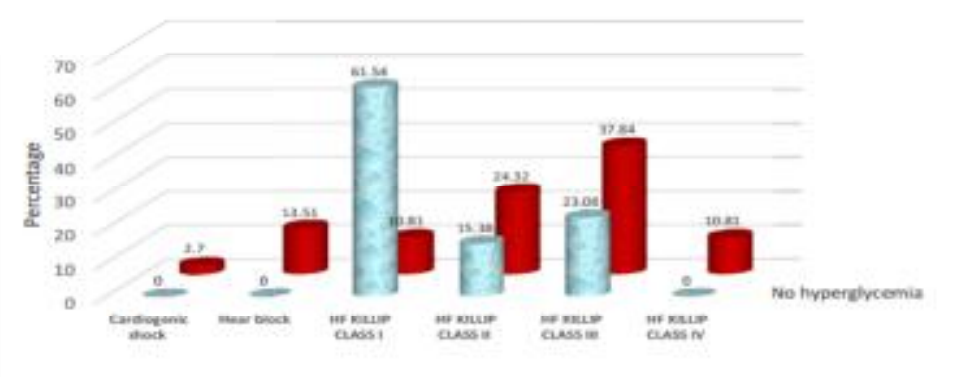

\section{DISCUSSION}

The patient enrolled in this study allowed us to explore the relation between admission hyperglycemia and outcomes across a broad range of glucose concentration in patients presented by acute coronary syndromes. We found evidence a linear trend between admission glycemia and complications, particularly left ventricular failure. This result is similar with a large study's findings.(6 -8)

Also elevated admission glucose is an important and significant predictor of in hospital outcome after STEMI and this is similar with the result of study by Rasoul et al.(9)

But the prior long term glucose dysregulation detected by HbAIC is a covariate of other high risk clinical characteristics of interest and significant observation in our study.(10-11)

The synergistic relationship between glucose level, c-reactive protein (hsCRP) and risk of clinical events remained statistically significant..

These findings suggest that the important deleterious biological interactions between glucose and $\mathrm{C}$ reactive protein observed in vitro could also be of clinically relevance in ACS patients.(12)

Although both HbAlcand admission glucose may be associated with impaired prognosis, our results indicate that increased admission glucose is more important. 
Higher admission glucose is associated with higher Killip class, larger infarct size and lower ventricular function.(13)

HbA1c may have limited predictive power for short-term outcomes in patients with ACS, but its association with long-term outcome may be stronger.(14)

Although stress-induced hyperglycaemia can partly explain the relation between admission glucose and outcome, hyperglycaemia itself can also be harmful. The thrombotic properties of platelets are increased in a hyperglycaemic environment, and this can result in additional cardiovascular complications.(15)

Moreover, recent reports suggest that glucose may be an important mediator in inflammatory responses. Elevated glucose levels induce an increase in inflammatory markers in healthy people, and hyperglycaemic patients with an acute myocardial infarction have an augmented inflammatory response compared to normoglycaemic patients.(16)

Similarly, Duarte et al(17), studying patients with ACS and complications, have found higher mean blood glucose levels, which were significantly associated with in-hospital events.

Our results showed a significant difference of mean CRP levels in patients of NSTEMI, STEMI as compared to UA patients and are in consistence with Zebrack et al(18)and Kazmierezak et al,(19)who identified increase in the CRP levels in patients of STEMI and NSTEMI versus UA, mainly due to myocardial necrosis and release of cytokines mediated CRP response.

A limited increase in the CRP levels in patients with UA could be due to low grade myocardial necrosis by ischemia.(20)
Our results are in agreement with Rubins et al(21)who showed that the major coronary risk factors were more common in patients with STEMI compared to UA and NSTEMI .

However, Perski et al(22)found smoking to be most common and significant risk factor in young patients with CHD.

\section{CONCLUSION}

ßElevated admission hyperglycaemia in patients with acute coronary syndromes of is an important predictor of in-hospital left ventricular failure especially in STEMI.

BACS diabetic patients have more inflammation than non-diabetic patients.

Increased inflammatory markers have the highest risk of adverse events...

\section{REFERENCES}

1. Ridker PM, Rifai N, Rose L, Buring JE, Cook NR. Comparison of C-reactive protein and low-density lipoprotein cholesterol levels in the prediction of first cardiovascular events. $\mathrm{N}$ Engl J Med. 2002;347(20):1557-65.

2. Clearfield MB. C-reactive protein: a new risk assessment tool for cardiovascular disease. J Am Osteopath Assoc. 2005;105(9):409-16 .

3. Pfützner A, Forst T. High-sensitivity Creactive protein as cardio vascular risk marker in patients with diabetes mellitus. Diabetes Technol Ther. 2006;8(1):28- 36.

4. Ritchie SA, Connell JM. The link between abdominal obesity, metabolic syndrome and cardiovascular disease. Nutr MetabCardiovasc Dis.2007;17(4):319-26.

5. Rasoul S,Ottevanger JP, Bilo HJ, Timmer JR,Van't Hof Aw,ambrink JH,Dikkeschei LD, Hoorntje Jc, de Boer MJ and Zijistra F. Neth J Med.2007 Mar; 65 (3): 95-100.

6. Foo K, S Cooper,C Knight, A Suliman, K Ranjadayalan and A DTimmis. Single Serum glucose measurement predicts adverse outcomes across the whole range of acute coronary syndromes. Heart 2003; May; 89(5):512-516.

7. Hadjads S, Coisne D, Mavco G, Ragot S, Duengler F, Sosner P, Torremocha F,Herpin D andMarechaudR.Prognostic 
value of admission plasma glucose and $\mathrm{HbA}$ inacute myocardial infarction.

Diabetes Med.2004; 21:305-310.

8. Isihara M, Inoue I, Kawagoe T, Shimatani Y. Kurisu S, Nishioka K. Umemura T, Nikamura S, andYoshida M.Impact of acute hyperglycemia on left ventricular function after reperfusion therapy in patients with first anterior myocardial infarction. Am Heart J. 2003; 164:674678.

9. Rasoul S,Ottevanger JP, Bilo HJ, Timmer JR,Van't Hof Aw, Dambrink JH, DikkescheiLD, Hoorntje Jc, de Boer MJ and Zijistra F.Glucose Dysregulation in non diabetic patients with St-elevation myocardial Infarction : Acute and chronic glucose dysregulation in STEMI. Neth J Med.2007 Mar; 65 (3): 95-100.

10.Timmer, JP, Ottervanger, H.S.G, Bilo, J.H.E Dambrink, K, Miedema, J.C.A and Zigilstra F.Prognositc value of admission glucose and glycosylated haemoglobin levels inacute coronary syndromes. J Med 2006;99:237-243.

11. Malmberg $\mathrm{K}$, Rydn $\mathrm{L}$, Wadel $\mathrm{H}$, Birkeland K, Bootsma A, Dickstink, Efendic S, Fisher M, Hamsten A.Herlitz J, Hildebrandt P, Macleod K, Laakso M, Torppederson $\mathrm{C}$, and Valdenstrom $\mathrm{A}$; DIEAMI $\mathrm{Z}$ Investigators. Intense Metabolic Control by means an insulin in patients with diabetes mellitus and acute myocardial infarction (DIGAMI Z): Effects on mortality and morbidity. Eur Heart J 2005; 26:650-61.

12.Kausik K, Christopher P, Canon, David A., Buros J, Rifai N, Carolyn H, Mc Cabe, C. Gibson $M$ andBraunwald E. Synergestic relationship between hyperglycemia and inflammation with respect to clinical outcomes in Non-ST elevation acute coronary syndromes; Analysis from OPUS - TIMI 16 and TACTICS - TIMI 18. European Heart Journal 2007 28(7):806813.

13.Timmer JR, Bilo HJG, Ottervanger JP, Dambrink JHE, Miedema K, Hoorntje JCA, Zijlstra F.Dysglycemia in suspected acute coronary syndromes. Eur J Intern Med2005; 16:29 9. Tenerz A, Nilsson G, Forberg R, Ohrvik J, Malmberg K, Berne C, Leppert J. Basal glucometabolic status has an impact on long-term prognosis following an acute myocardial infarction in non-diabetic patients. J Intern Med 2003; 254:494-503.

14.Gresele P, Guglielmini G, De Angelis M, Ciferri S, Ciofetta M, Falcinelli E, Lalli C, Ciabattoni G, Davi G, Bolli GB.Acute, short-term hyperglycemia enhances shear stress-induced platelet activation in patients with type II diabetes mellitus. J Am Coll Cardiol 2003; 41:1013-20.

15.Lind L, Fugmann A, Branth S, Vessby B, Millgard J, Berne C, Lithell H.The impairment in endothelial function induced by non-esterified fatty acids can be reversed by insulin. Clin Sci (Lond) 2000; 99:169-74.

16.Marfella R, Siniscalchi M, Esposito K, Sellitto A, De Fanis U, Romano C,Portoghese M, Siciliano S, Nappo F, Sasso FC, Mininni N, Cacciapuoti F, Lucivero G, Giunta R, Verza M, Giugliano D. Effects of stress hyperglycemia on acute myocardialinfarction: role of inflammatory immune process infunctional cardiac outcome. Diabetes Care 2003; 26:3129-35.

17.Esposito K, Nappo F, Marfella R, Giugliano G, Giugliano F, Ciotola M, Quagliaro L, Ceriello A, Giugliano D. Inflammatory cytokine concentrations are acutely increased by hyperglycemia in humans: role of oxidative stress. Circulation 2002; 106:2067-72

(18. Duarte ER, Pellanda LC, Portal VL. Perfil inflamatório, metabólico e lipídico na síndrome isquêmica aguda: relação com eventos intra e pós-hospitalares. Arq Bras Cardiol. 2005;84(2):122-9.

(19. Zebrack JS, Anderson JL, Maycock CA, Horne BD, Bair TL, Muhlestein JB. Usefulness of high-sensitivity $\mathrm{C}$ reactive protein in predicting long term risk of death or acute myocardial infarction in patients with unstable or stable angina pectoris or acute myocardial infarction. Am J Cardiol 2002;89:145:9.

(20.Cusack MR, Marber MS, Lambiase PD, Bucknall CA, Redwood SR. Systemic inflammation in unstable angina is the result of myocardial necrosis. J Am Coll Cardiol 2002;39:1917-23.

(21.Rubins HB, Robins SJ, Collins D, Fye CL, Anderson JW, Elam MB, et al. Gemfibrozil for the secondary prevention of coronary heartdisease in men with low levels of high-density lipoprotein 
cholesterol. Veterans Affairs high-density lipoprotein cholesterol intervention trial study group. N Engl J Med 1999;341:4108.

(22.Perski A, Olsson G, Landou C, de Faire U, Theorell T, Hamsten A. Minimum heart rate and coronary atherosclerosis: independent relationsto global severity and rate of progression of angiographic lesions in men with myocardial infarction at a young age. Am Heart J 1992;123:609-16. 